Dr Jordi Sánchez-Martí

University of Alicante

Dept of English Philology

03080 Alicante, Spain

E-mail: Jordi.Sanchez@ua.es

\title{
Zelauto's Polinarda and the Palmerin Romances
}

In 1580 the printer John Charlewood issued the romance Zelauto: The Fountaine of Fame (STC 18283), which represents, as its modern editor states, ‘Anthony Munday’s single original contribution to Elizabethan prose fiction'. ${ }^{i}$ Munday's originality, however, is not to be understood as the product of an independent and isolated author immune to contemporary trends in literature, but rather the opposite. While Munday is Zelauto's sole creator, he benefitted from narrative models available to him, including the biblical parable, court panegyric, medieval sermon, romantic-comic novella and chivalric romance. ${ }^{\text {ii }}$ Additionally, as was typical of the Renaissance, the text is punctuated with frequent references to classical history and literature, although literary references in Zelauto are not limited to texts and authors of classical times, but interestingly also include characters from the Iberian chivalric romances, a textual corpus imitated by Munday. ${ }^{\text {iii }}$ In the first part of Zelauto, its titular hero reads to his host Astraepho from a book narrating a knightly contest between an armed lady and a rude knight. The latter takes issue with the former apropos of Queen Elizabeth's personal qualities, previously extolled by the lady in the text. The knight argues, 'Haue I condempned my peereless Pollinarda: and aduaunced the Fame of this Princes [i.e., Queen Elizabeth]? Haue I left my natiue Countrey, wherein abound choyse of delycate Dames, hoping that this should surpasse them all?' (p. 44). Since Stillinger's edition contains no note explaining this and other two occurrences of the name Polinarda / Pollinarda (pp. 44, 49), I propose to shed light not only on the origin of this reference, 
but also on its possible narrative rationale in order to better interpret its function in Zelauto and draw some conclusions about Munday’s literary career.

The name Polinarda derives from the Palmerin cycle of Iberian chivalric romances, which circulated in Elizabethan England thanks to Munday’s translations. ${ }^{\text {iv }}$ This cycle originated in 1511 with the publication of the Spanish Palmerín de Olivia, where Polinarda appears as the eponymous hero's beloved and eventually his wife. ${ }^{\mathrm{v}}$ There is also a Portuguese continuation, Palmeirim de Ingalaterra, written by Francisco de Moraes ca. 1543-44, which features the same Polinarda along with her granddaughter and namesake. The latter is Palmerin d'Oliva's granddaugther, daughter of Primaleon and Gridonia and beloved of Palmerin of England. ${ }^{\text {vi }}$ Which one of the two Polinardas is meant by Munday in Zelauto?

The rude knight remembers his peerless Polinarda after hearing how the armed lady praises Elizabeth, 'the seemlyest Queene, / that euer nature bred' (p. 41) and 'this gallant Gem’ (p. 44). In a rather indecorous manner he expresses his difference of opinion, considering such an exaltation excessive and even inspired by self-serving motives. The rude knight then challenges the armed lady to defend in combat her lavish and unstinting praise of the Queen: 'If you [i.e. the armed lady] of your selfe are able to auouch what is spoken, and of sufficient force to stand to your boasting? doubt not but you shall be dealt with all before you depart' (p. 44). In short, they agree to fight in a judicial combat to determine who is worthier, whether Polinarda or Queen Elizabeth. Just as the knight in Zelauto fights to assert that his Polinarda is unsurpassable, there are parallel episodes in the Iberian romances affecting each Polinarda individually.

In the same way as the armed lady praises Elizabeth in Zelauto, in Palmerin d'Oliva Lewes, son to the king of France, holds a very high opinion of his beloved the Duchess of Burgundy, of whom he says 'that nature neuer made a more perfect creature'. vii To 
uphold this claim and as testimony to his devotion to the Duchess, Lewes announces in front of a group of knights, 'I will make good my words by deedes of Armes, against anie Knight whatsoeuer that dare saie the contrarie' (sig. V1 ${ }^{\mathrm{r}}$ ). When Lewes's challenge comes to Palmerin d’Oliva's attention, he 'in the ende concluded the Combat, viii perswading him selfe ... [n]eyther Empresse, Queene [n]or Ladie was more accomplished with perfections, then his gracious Mistresse Polinarda' (sig. X1 ${ }^{\mathrm{r}}$ ). Palmerin d'Oliva is prepared to fight for the supremacy of his Polinarda, in the same way as the rude knight does in response to the armed lady's views on the Queen. In the end Polinarda, Palmerin d'Oliva's future wife, is proved in the field of battle to be unsurpassable.

In Palmerin of England the eponymous hero finds himself at a similar juncture in having to assert that the beauty of his beloved Polinarda, Palmerin d'Oliva's granddaughter, is superior to that of the Spanish lady Miragarda, who was kept in a castle by her father precisely because of her extraordinary attractiveness. Miragarda’s champion is actually Polinarda's brother, Florendos, who here adopts the epithet 'the Tristfull Knight’. Palmerin of England, unlike the rude knight in Zelauto and Palmerin d'Oliva, seems to act more out of chivalric responsibility than real conviction, since he puts Miragarda in a category all of her own on account of her beauty:

when he [i.e. Palmerin of England] sawe the Picture of Miragarda, which represented such beautie as his sences were rauished, he could proceed no farther till he had vsed these speeches. Certainly Madame [i.e. Miragarda], I see at this present the thing I neuer thought to doo, and cannot thinke amisse of your knight, who may well hazard his life for so rare a Goddesse. ${ }^{\text {ix }}$ 
Notwithstanding his bewilderment, Palmerin feels morally obliged to proclaim Polinarda's superior beauty, thus prompting Florendos to retaliate and start the combat. In contrast to what happens in Palmerin d'Oliva, Palmerin of England fails to overcome Florendos and hence to prove her beloved to be unrivalled. ${ }^{\mathrm{x}}$ Aware of Palmerin’s unmatched martial abilies, Florendos gives a logical explanation for the combat's outcome: 'What man is he, albeit his state were oppressed with neuer so much debilitie, that woulde not assure himselfe to remaine victor, maintaining the quarrell of so excellent and rare a Jewell [i.e. Miragarda]?’ (sig. S3 ${ }^{r}$ ). In other words, in view of the evidently unsurpassable beauty of Miragarda, any knight would be in a position to acquit himself for her sake, no matter the opponent. As happens in Zelauto, Polinarda's primacy is not upheld in the field of battle, although there is a slight difference: while in Palmerin of England Florendos is unable to defeat the titular hero because of the latter's chivalric prowess, in Zelauto the armed lady vanquishes her opponent in spite of her physical 'debilitie' typically associated with women. The armed lady puts forward the very same argument of supposed female weakness: 'although God hath giuen the greater courage, the more magnanimitie, and the bolder behauiour to your Sex [i.e. the rude knight's]: he hath vtterly reiected the weaker vesselles' (p. 45). ${ }^{\mathrm{xi}}$ In sum, in the light of Queen Elizabeth’s overwhelming superiority, the armed lady’s acknowledged 'debilitie' is no impediment to her victory over the rude knight, as Florendos in the passage quoted above anticipates for any defender of Miragarda’s beauty.

Either the episode in Palmerin d'Oliva or in Palmerin of England could have provided inspiration to Munday. Donna Hamilton seems to identify the Polinarda in Palmerin of England with the character mentioned in Zelauto, ${ }^{\mathrm{xii}}$ and there is further textual evidence in support of her view. At the end of the prefatory epistle dedicating Zelauto to Edward de Vere, 17th earl of Oxford, Munday announces, 'Not long it will 
be before ... the renowned Palmerin of England with all speede shall be sent you' (p. 6). That is to say, when Zelauto went to press Munday's translation of the lengthy Palmerin of England was well under way. We know that John Charlewood obtained licence to print it on 13 February 1581, xiii although the earliest edition that survives is dated 1596. Considering the lack of positive evidence some scholars have questioned that an earlier edition was ever printed, ${ }^{\text {xiv }}$ but the presence of the words “"Palmeryng”, 2 parts' in a list of books dated 1585 belonging to the bookseller Thomas Marshe confirms that Palmerin of England must have been printed between 1581 and $1585 .{ }^{\mathrm{xv}}$ It seems therefore accurate that his composition of Zelauto coincided with his translation of Palmerin of England, and thus it appears natural that Munday could have borrowed from an episode in the text he was translating. ${ }^{\text {xvi }}$

Notwithstanding this circumstantial evidence, both textual and historical, suggesting that Munday was influenced by the episode in Palmerin of England, we need to explore whether it is possible that he could also know the episode in Palmerin d'Oliva or not. It is likely that Munday was busy translating the latter between 1585 and $1587,{ }^{\text {xvii }}$ few years after the publication of Zelauto and right after the appearance of Palmerin of England. This assumption does not necessarily mean, however, that Munday could not have previously become acquainted with the inaugural work of the Palmerin cycle. Munday’s direct knowledge of the Iberian chivalric romances probably started during his time in Rome, from the autumn of 1578 until the summer of 1579, an experience he describes in his book The English Roman Life, published by Charlewood in 1582 (STC 18272). Here Munday reveals one of the reasons behind his decision to travel abroad, 'affection to learn languages', including both French and Italian. ${ }^{\text {xviii }}$ It is not unlikely that being in Italy he could have obtained a copy of the Historia del valorosissimo cavalliere Palmerino d'Oliva, translated by Mambrino Roseo da Fabriano, and printed 
on numerous occasions between 1544 and $1575 .{ }^{\text {xix }}$ In fact, the text of Munday’s Palmerin d'Oliva reveals that he consulted the Italian version of Mambrino and copied the form of personal names in the romance. ${ }^{\mathrm{xx}}$ In other words, it seems that Munday could have read the Italian version of Palmerin d'Oliva long before he started preparing the English translation. And there is additional textual evidence confirming that while in the process of translating Palmerin of England Munday was perfectly familiar with Palmerin d'Oliva. In chapter 64 of the second part of Palmerin of England, published not later than 1585, Munday includes the following remark involving Palmerin d'Oliva:

Of this birde, you may reade more at large in the notable and famous History of the Emperour Palmerins life, which Booke is called Palmerin d'Oliue, a History plentifully stored with discourses of singular delight, being for the woorthinesse thereof, esteemed of many Nations, as this History [i.e. Palmerin of England] is likewise: and therefore, for the excellencie of this aforesayd History [i.e. Palmerin of England], and in respect it [i.e. Palmerin of England] dependeth on matters breefely touched in this booke [i.e. Palmerin d'Oliva], so that it [i.e. Palmerin d'Oliva] is accounted as a parcell of this History [i.e. Palmerin of England], I entend (God ayding mee), to publish it shortly [i.e. Palmerin d'Oliva], when (I doubt not) but the Gentle Reader shall finde it worthy of the commendations that I haue vsed of it in this place. ${ }^{x x i}$

The bird in question is a prophetic one that makes its first appearance in the Spanish Palmerín de Olivia, ch. 131, corresponding to the English Palmerin d'Oliva, part II, ch. 50. ${ }^{\text {xii }}$ This cross-reference between the romances Palmerin of England and Palmerin d'Oliva is original to Munday, since it is not contained in the French version of 
Palmerin d'Angleterre from which he translated. ${ }^{\text {xxiii }}$ Therefore, it seems probable that before finishing both his translation of Palmerin of England and his Zelauto and before starting his translation of Palmerin d'Oliva, Munday was capable of establishing a connection with an episode from the final section of the latter, thus making apparent his profound knowledge of this romance.

Finally, there is one additional consideration we need to make about Zelauto's Polinarda. From the outset, the fact that she is introduced in the story with no further information should make us think immediately of Palmerin d'Oliva's beloved, simply because she is the founder of the lineage to which the other Polinarda belongs. Besides, a distinction would seem more necessary in the case of Palmerin of England, simply because both the matriarch and her granddaughter are featured in it, even though the former plays a minor role. Taking these considerations into account one would be inclined to believe that the Polinarda mentioned in Munday’s Zelauto refers to the character in Palmerin d'Oliva. This identification, however, shall remain hypothetical unless we obtain convincing proof that Munday did become acquainted with a version of Palmerin d'Oliva in or before 1580.

This exploration of the episodes in Palmerin of England and Palmerin d'Oliva has shown that Munday's reference to Polinarda in Zelauto could have been influenced equally by one or the other. Maybe he just wanted to evoke the defense Palmerin heroes make of their beloved's beauty and create the expectation of a similar response from the rude knight. In any event, we cannot pinpoint with certainty which one of the two Polinardas Munday had in mind. Unexpectedly, the analysis of all the available evidence has disclosed significant information concerning Munday’s literary practices and inclinations. When Zelauto was published in 1580, the reference to Polinarda was unintelligible to Munday's immediate audience, since no translation of the Palmerin 
cycle was yet available in England. It is not that Munday intended for his work to remain obscure or for his remark to be cryptic, but rather that Zelauto was published prematurely, as the author declares in the prefatory epistle: 'The last part of this woorke remaineth vnfinished, the which for breuity of time, and speedines in the Imprinting: I was constrained to permit till more limitted leysure' (p. 6). Munday appears as subordinate to John Charlewood, ${ }^{\text {xxiv }}$ who needed to churn out more material regardless of its incompleteness, thus altering Munday’s plans for his original work.

We know that Munday had carefully planned and advertised the serialization of his romance translations, ${ }^{\mathrm{xxv}}$ so it is not unlikely that he envisaged to publish his original prose romance right after the publication of his translations of Iberian romances, when his efforts could have been more properly appreciated and valued. Certain of the commercial success of the Palmerin romances, Munday's creative impulse was driven by his acute commercial instincts, ${ }^{\text {xxvi }}$ but his plans were thwarted by the printer, whose priorities and criteria were different from those of his author and translator. Charlewood, like any other regular printer, was concerned with the financial viability of his business and made his publishing decisions based on his first-hand knowledge of the book market. Just as he chose to print Zelauto when it was still unfinished, it seems reasonable then to attribute to Charlewood the decision to vary the order of the Palmerin romances. Rather than starting with the publication of the inaugural title of the cycle, i.e. Palmerin d'Oliva, Charlewood erred on the side of caution and chose to print first Palmerin of England. This decision most probably met with Munday's disapproval as can be gathered from the revised dedication he prepared for the second edition of Palmerin d'Oliva published in 1597: 'Though in my translating they came last which should haue bin first, now I haue good hope, that by the reprinting of them ouer againe, at length they will come to a iust order, and each haue his place as their course 
describeth' ${ }^{\text {xxvii }}$ Munday was aware of the Palmerin romances’ natural narrative order, but Charlewood, impervious to these texts' literary sequentiality, decided to alter the internal order of the cycle, hopeful that the geographical provenance of the titular hero might spark the interest of the English public. ${ }^{\text {xxviii }}$ It was a sort of trial run for the romance translations that must have fulfilled the printer's expectations.

To conclude, while this article has identified two episodes from the Palmerin romances that could have equally inspired Munday to mention Polinarda in Zelauto, it has been unable to positively confirm the individual character the author had in mind. In conducting this examination, it has become apparent how Munday's literary project was contingent on the needs, priorities and decisions of a down-to-earth printer whose responsibility was to make his business profitable by satisfying his potential customers' tastes and preferences. ${ }^{\text {xxix }}$ 
${ }^{\mathrm{i}}$ Zelauto: The Fountaine of Fame, ed. by Jack Stillinger (Carbondale: Southern Illinois University Press, 1963), vi. All my quotations from Zelauto refer to this edition. STC refers to A. W. Pollard and G. R. Redgrave, A Short-Title Catalogue of Books Printed in England, Scotland and Ireland 1475-1640, 2nd edn, rev. and enlarged by W. A. Jackson, F. S. Ferguson and Katharine F. Pantzer (London: Bibliographical Society, 1986-91), 3 vol.

${ }^{\text {ii }}$ For the identification of these generic models used by Munday, see Paul A. Scanlon, ‘Munday’s Zelauto: Form and Function’, Cahiers Élisabéthains 18 (1980), 11-17. Scanlon makes no reference to chivalric romance, which played an important role in defining the overall structure of the story; cf. Stillinger, ed., Zelauto, xvi. iii For an overview of the whole corpus of Iberian romances and its circulation in early modern England, see Henry Thomas, Spanish and Portuguese Romances of Chivalry: The Revival of the Romance of Chivalry in the Spanish Peninsula, and its Extension and Influence Abroad (Cambridge: Cambridge University Press, 1926).

iv The Palmerin romances he translated are Palmerin d'Oliva (STC 19157), Palmerin of England (STC 19161), Palmendos (STC 18064), and Primaleon of Greece (STC 20366). For further information, see Gerald R. Hayes, ‘Anthony Munday’s Romances of Chivalry’, The Library, 4th. ser., 6 (1925), 57-81; Mary Patchell, The 'Palmerin' Romances in Elizabethan Prose Fiction (New York: Columbia University Press, 1947); and Donna B. Hamilton, Anthony Munday and the Catholics, 1560-1633 (Aldershot: Ashgate, 2005), ch. 3. 
${ }^{\vee}$ See Palmerín de Olivia, ed. by Giuseppe di Stefano with the assistance of Daniela Pierucci, Los Libros de Rocinante, 18 (Alcalá de Henares: Centro de Estudios Cervantinos, 2004).

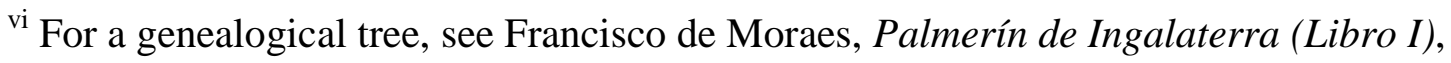
ed. by Aurelio Vargas Díaz-Toledo, Los Libros de Rocinante, 23 (Alcalá de Henares: Centro de Estudios Cervantinos, 2006), 242. The Portuguese original is edited by Geraldo de Ulhoa Cintra (São Paulo: Editora Anchieta, 1946).

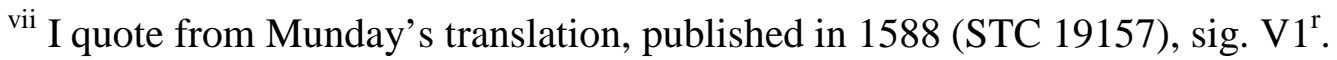

viii I.e., he decided to take part in the combat; see $O E D$, s.v. conclude, v. 14.

${ }^{\text {ix }}$ I quote from Munday’s translation of Palmerin of England published in 1596 (STC 19161), sig. $S 2^{\mathrm{V}}$.

${ }^{\mathrm{x}}$ To be precise, in Palmerin d'Oliva the hero does not prevail over his rival Frisol either, but the reason is that both the two knights champion the same lady, i.e. Polinarda.

${ }^{\mathrm{xi}}$ Vessel, i.e. 'the body, esp. as the receptacle of the soul', $O E D$, n. ${ }^{1}$ 3b. xii See Munday and the Catholics, 17, 85.

xiii See Edward Arber, A Transcript of the Registers of the Company of Stationers of London, 1554-1640 AD (London, 1875-94), II, 388. For biographical information on Charlewood, see H. R. Tedder, 'Charlewood, John (d. 1593)', rev. Robert Faber, in Oxford Dictionary of National Biography, ed. by H. C. G. Matthew and Brian Harrison (Oxford: Oxford University Press, 2004), XI, 176-77.

${ }^{\text {xiv }}$ Cf. Hamilton, Munday and the Catholics, 86, and more explicitly in her article ‘Anthony Munday and The Merchant of Venice', Shakespeare Survey 54 (2001), 94 n. 
30; and William E. Purser, Palmerin of England: Some Remarks on This Romance and on the Controversy Concerning Its Authorship (Dublin: Browne and Nolan, 1904), 391. ${ }^{x v}$ See Henry R. Plomer, 'Some Elizabethan Book Sales’, The Library, 3rd ser., 7 (1916), 328. This allusion can refer only to Palmerin of England, since Palmerin d'Oliva did not appear until 1588; see Jordi Sánchez-Martí, 'The Publication History of Anthony Munday’s Palmerin of England', Gutenberg-Jahrbuch 89 (2014), 190-207. Gerald R. Hayes, in 'Melzi’s Dating of “Palmerino di Inghilterra”, Part III’, The Library, 4th ser., 7 (1927), 409-13, suggests that Munday’s Palmerin of England could have been published only between 1584 and 1587 (p. 413), although his conclusion is inaccurate due to an incomplete knowledge of the Italian editions of the romance, for which see Stefano Neri, 'Cuadro de la difusión europea del ciclo palmeriniano (siglos XVI-XVII)’, in Palmerín y sus libros: 500 años, ed. by Aurelio González et al. (Mexico: Colegio de México, 2013), 285-313, esp. p. 294.

${ }^{\text {xvi }}$ When describing Anthony Munday’s literary career, John Jowett states, ‘a decade later [i.e. after the publication of Zelauto in 1580] he was busy translating extravagantly long romances such as Palmerin d'Oliva (1588)', Sir Thomas More, ed. by John Jowett (London: Arden Shakespeare, 2011), 10. It seems more accurate to describe the composition of Zelauto as concurrent with the translation of romances such as Palmerin of England.

xvii See Sánchez-Martí, 'Publication of Munday’s Palmerin d'Oliva', 193.

xviii The English Roman Life, ed. by Philip J. Ayres (Oxford: Clarendon Press, 1980), 5.85. In 1579 Munday also explained his motivation to travel to Rome, namely, 'to attaine to some vnderstanding in the languages, considering in time to come: I might reap therby some commoditie', A Mirrour of Mutabilitie (STC 18276), ed. by Hans 
Peter Heinrich (Frankfurt: Peter Lang, 1990), 7.13-15; see also p. 8.42-43. An account of Munday’s trip to Rome is included in Celeste Turner, Anthony Mundy: An Elizabethan Man of Letters (Berkeley: University of California Press, 1928), 16-23. For a more concise and up to date biography, see David M. Bergeron, 'Munday, Anthony (bap. 1560, d. 1633)', in Oxford Dictionary of National Biography, XXXIX, 739-46. ${ }^{\text {xix }}$ For bibliographical descriptions of the editions produced by Michele Tramezzino, see Alberto Tinto, Annali tipografici dei Tramezzino (Venice: Olschki, 1968), nos 51, 65, 118, 166, and 179. See also Neri, ‘Cuadro de la difusión europea del ciclo palmeriniano’, 288.

${ }^{\text {xx }}$ See Giuseppe Galigani, ‘La versione inglese del "Palmerín de Olivia”’, in Studi sul Palmerín de Olivia (Pisa, 1966), III, 252.

${ }^{x x i}$ Palmerin of England, part II (1596; STC 19161), sig. Ee5 ${ }^{\mathrm{v}}$. This edition was a reprint of the now lost editio princeps; cf. Hayes, ‘Munday’s Romances of Chivalry’, 59. I have chosen to disambiguate all references in this passage to render it easily understandable.

${ }^{\text {xxii }}$ For an analysis of this bird and its narrative function, see Javier Roberto González, 'El ave profeta en Palmerín de Olivia y Primaleón', Exemplaria 4 (2000), 73-107. It is significant that in this excerpt Palmerin d'Oliva is presented as 'esteemed of many Nations', thus suggesting that Munday had some knowledge of this romance's textual history and dissemination. The title page of the first edition of Palmerin d'Oliva explicitly states that it was 'Written in the Spanish, Italian and French, and from them turned into English’; for a facsimile reproduction, see Sánchez-Martí, 'Publication of Munday's Palmerin d'Oliva', 194, fig. 1. By contrast, the title page of Palmerin of 
England mentions only French, without alluding to the Italian, Spanish and Portuguese versions.

xxiii Hayes, 'Dating “Palmerino”', 412, argues that Munday used the 1574 edition of the French Palmerin d'Angleterre. For bibliographical information about the French edition of 1574, see Andrew Pettegree et al., eds, French Vernacular Books: Books Published in the French Language before 1601 (Leiden: Brill, 2007), nos 40409-12. For the corresponding section in the French text, see Histoire du preux, vaillant et tres victorieux chevalier Palmerin d'Anglaterre (Paris, 1574), sig. $\mathrm{KK}^{\mathrm{v}}$.

xxiv Munday and Charlewood had a long-lasting relationship that started at least in 1577 when the latter printed the former’s first work (STC 18269.5).

${ }^{x x v}$ See Louise Wilson, ‘Serial Publication and Romance’, in The Elizabethan Top Ten: Defining Print Popularity in Early Modern England, edited by Andy Kesson and Emma Smith (Farnham: Ashgate, 2013), 214-21.

${ }^{x x v i}$ For the popularity and profitability of the long prose romances, including the Palmerin cycle, see Holger Schott Syme, 'Thomas Creede, William Barley, and the Venture of Printing Plays', in Shakespeare’s Stationers: Studies in Cultural Bibliography, ed. by Marta Straznicky (Philadelphia: University of Pennsylvania Press, 2013), 28-46. For Munday’s commercial instincts, see Tracey Hill, Anthony Munday and Civic Culture: Theatre, History and Power in Early Modern London, 1580-1633 (Manchester: Manchester University Press, 2004; repr. 2009), 44-68.

${ }^{\text {xxvii }}$ I reproduce the text from the dedicatory epistle as printed in the 1615/1616 edition of Palmerin d'Oliva (STC 19159a; sig.A3 ${ }^{\mathrm{r}}$ ), because the prefatory material of the second edition is missing in the two extant copies. Since the first part of the third edition derives from the second edition (STC 19158), it seems safe to assume that the 
epistle in the second edition carried the same text; cf. Sánchez-Martí, 'Publication of Munday's Palmerin d'Oliva', 196 n. 35. The same idea is repeated in the address 'To the courteous Reader' that appears at the end of The Second Part of Palmerin of England (1616; STC 19163): 'As for the History of Palmerin d'Oliue, which containeth three seueral parts, and should haue bin translated before this, or Primaleon of Greece, because they are the originall of all the other stories' (sig. Ff6 ${ }^{\mathrm{r}}$ ). See also Louise Wilson ‘Playful Paratexts: The Front Matter of Anthony Munday’s Iberian Romance Translations', in Renaissance Paratexts, edited by Helen Smith and Louise Wilson (Cambridge: Cambridge University Press, 2011), 126.

xxviii The nationalist implications of Charlewood's choice were later verbalised by Munday himself. For instance, in the address 'To the courteous Reader' of The Second Part of Palmerin of England (see n. 27), Munday states that the existence of a work such as Palmerin of England 'is to the honour of our countrey of England, and deuised by strangers, to honor it the more' (sig. $\mathrm{Ff6}^{\mathrm{r}}$ ); for this idea, see Louise Wilson, 'The Publication of Iberian Romance in Early Modern Europe’, in Translation and the Book Trade in Early Modern Europe, ed. by José María Pérez Fernández and Edward Wilson-Lee (Cambridge: Cambridge University Press, 2014), 212. A similar consideration appears in the post-face to Palladine of England (1588; STC 5541), where the national interest of the romance is commended: 'in meane while (for Countries sake) bid Palladine welcome, which the French haue published in the honor of England' (sig. Aa4v). Neither Charlewood nor Munday was the first in appealing to their text's national relevance for commercial purposes, since Nicolas de Herberay des Essarts, the French translator of the Spanish Amadís de Gaula, had already invoked the Frenchness of this romance's hero in the first edition of the French translation, published in 1540; 
see Jane H. M. Taylor, Rewriting Arthurian Romance in Renaissance France: From Manuscript to Printed Book (Cambridge: D. S. Brewer, 2014), 163-67.

${ }^{x x i x}$ Research for this article was funded by the Spanish Ministry of Science and Innovation (ref. FF12011-22811), whose support is herewith gratefully acknowledged. 